\title{
The contrasting structure of Acts 12:5-17: A spatial reading
}

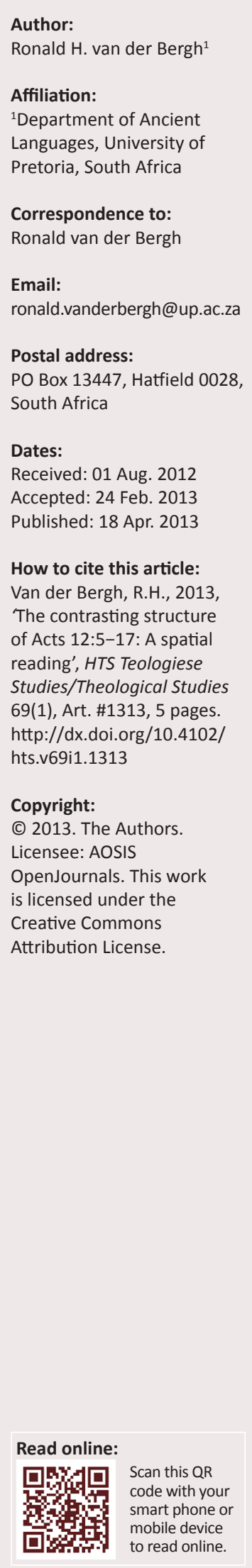

The episode of Peter's rescue from prison in Acts 12:5-17 occupies an intriguing position in the narrative of Acts as a whole. Scholars hold differing views on the episode's function. These views range from seeing the episode as a hermeneutical key to the work as a whole to making no discernable difference to the narrative whatsoever. The present article seeks to contribute to the debate by reading Acts 12:5-17 spatially. In paying attention to the various spatial references in the text, the movement of characters, their locales and their own and the reader's experience of them being present or not present, a contrasting structure may be perceived in the text. Furthermore, spatiality helps to point out the contrast between different character groups in the narrative. Some implications for reading the episode in this contrasting fashion will be indicated, and the enigmatic statement about Peter's 'going to another place' (Ac 12:17) will be read against the text's spatial background.

\section{Introduction}

Acts 12:5-17 occupies an intriguing position in the narrative of Acts. Scholars hold differing views on the text's function. These views range from seeing the text as a hermeneutical key to the work as a whole, to making no discernable difference to the broader narrative whatsoever (cf. Gaventa 2003:182; Marshall 1987:192-93; Wall 1991:628-30). Previous studies on this text are mostly concerned with historical questions such as redaction criticism, source criticism and the interplay between this text and other texts. ${ }^{1}$

The present article seeks to contribute to the debate from a different angle: by reading Acts 12:5-17 spatially. 'Spatiality' is here applied as a literary concept, namely, any reference to space contained in the text, whether stated explicitly or implicitly. The term also encapsulates movement, an action which cannot occur without reference to space (cf. Bar-Efrat 1989:184-185). A spatial reading such as the present article, then, is a reading which pays close attention to spatial referents in a given narrative. In other words, this article will offer a synchronic reading of the Acts 12:5-17 narrative with a focus on space. ${ }^{2}$

The structure of Acts 12:5-17 will first be delineated by way of its spatial attributes. Through this structure, various spheres of spaces will become evident, these spheres will then be investigated. This investigation will highlight contrasts within the text, especially with regard to the section's characters. Finally, the concept of movement within the text will be discussed in light of its spatial structure.

\section{A spatial reading of Acts 12:5-17 \\ Structure and delimitation}

Acts 12:5-17 is made up of two episodes (Ac 12:5-11 and Ac 12:12-17), a fact that can be deduced from its spatial attributes. The first of these spatial attributes, setting up a schema for the two episodes to follow, is found in Acts 12:5. ${ }^{3}$ Here, the construction $\mu \dot{\varepsilon} v$... $\delta \dot{\varepsilon}$ creates a contrast

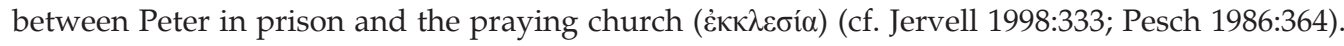
The action of the two episodes of Acts 12:5-17 unfolds within the spaces allocated by this contrast in Acts 12:5. The praying church is in a safe space, and Peter's problem will be resolved by moving from the prison, a dangerous space, to where the church is gathered.

1.For instance, several allusions to other texts and biblical or early Christian motifs have been identified, most prominent amongst
which are the exodus tradition, parallels with Jesus's passion, or a combination of these two (cf. Strelan 2004:271). Other suggested
references include Homer's lliad (MacDonald 2003), Euripides's Bacchae, Daniel (Parry 1995:162), Jonah (Williams 1964:152ff.) and the
deliverance of Moses as told by Artapanus (in Eusebius Praep. Ev. 9.27.12) (cf. Marshall 1987:208; Parry 1995:156).
2.The choice for a synchronic reading is not to deny the validity of diachronic readings or readings concerned with intertextuality, but
simply to take serious the finished product of the text as it stands before its readers today. In fact, it is hoped that this present
endeavour will support and contribute to methods with a different hermeneutical point of departure.

3.Acts 12:5 functions as a lynchpin: it is a summary of Acts 12:1-4 and an introduction to Acts 12:6-17. The preceding four verses (Ac 12:1-4) have set the scene for the two episodes, supplying the reason why Peter finds himself in this precarious position. 
The two episodes are framed by spatial references, that is to say, spatial references occur at the start and end of each episode. The two outer frames created in this way stand in contrast to each other: the first episode is framed by references to a stationary position, whilst the second episode is framed by references to movement. In the first episode, Acts 12:5-11, Peter starts in a stationary position ('he was sleeping' $-\tilde{\eta} v$

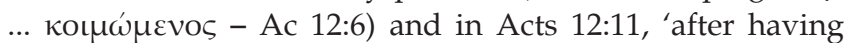

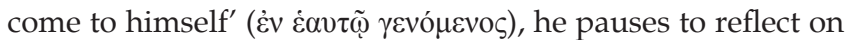
how the Lord has freed him. ${ }^{4}$ In a similar fashion, the second episode (Ac 12:12-17) is delineated by two verbs of motion:

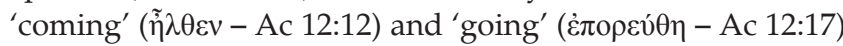
(cf. Weaver 2004:172). Additionally, the first episode is denoted by a frame within its outer frame: the appearance

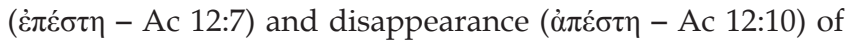
the angel (cf. Pervo 2008:299).

There is also a spatial contrast within the two outer frames set up by the spatial references at the beginning and start of each episode. The frame of stationary verbs in the first episode (Ac 12:5, 11) stand in relief to the successive use of verbs of

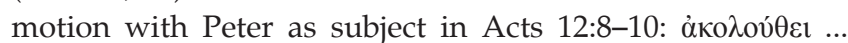

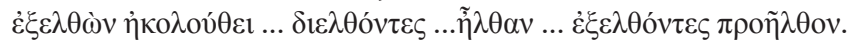
The second episode's frame of motion is contrasted with a stationary centre, at least with regard to the protagonist, Peter. No mention is made of Peter entering the gateway's door on which he is knocking; not even the move towards the gateway by the church community is narrated. The only

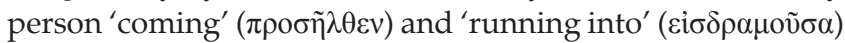
in this second episode is Rhoda. Rhoda's movement is in contrast with the stationary nature of the guards in the first episode. (This contrast will be discussed in more detail below, under the section on characters.)

A key spatial contrast within the two episodes is set up between the 'gate' ( $\dot{\eta} \pi v \dot{\lambda} \eta$ ) in the first episode in Acts 12:10,

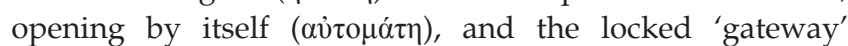
(o $\pi v \lambda \omega v$ ) in the second episode in Acts 12:13 (Kratz 1979:470). ${ }^{5}$ The two terms are not synonymous, but similar enough to be striking. The difference in terminology is pragmatic: whereas $\pi v ́ \lambda \eta$ would best describe the 'eiserne, schwer bewegliche Tür' (Bauernfeind 1980:163) of a prison, a $\pi v \lambda \omega$ ' v was more fitting to describe the gateway of a house (Kistemaker 1990:443), leading to the courtyard. Both gate and gateway receive special emphasis in the text. The $\pi \dot{v} \lambda \eta$ of Acts 12:10 is highlighted by the awkward resumptive use of a relative

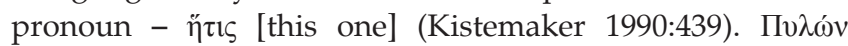
is highlighted by the use of antistrophe, that is, the term's repetitive use in the final position of consecutive phrases in Acts 12:13-14 (Parsons 2008:176). ${ }^{6}$ The gate and gateway divide Acts 12:5-17 into three spheres - the (private) inside

4.Peter's stationary position can be seen even more lucidly when the static čv in the

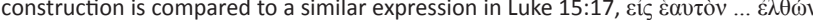
['he came to himself'].

5.At first glance the appearance of another term for a portal, $\theta 0$ ó $\alpha$ ('door' - Ac 12:6, 13), seems to disturb the spatial balance. However, this term is not emphasised; in 13), the second reference to the location of the first $\theta$ íp is don by way of another fact, the second reference to the location of the first term, $\pi \rho \omega \tau \eta \nu$ is a necessary prop, as Peter cannot knock on the gateway itself.

6.Parsons (2008:176) refers the reader to the definition and use of antistrophe as found in Rhet. Her. 4.13.19. of Herod's prison, the (public) outside, and the (private) inside of Mary's house (cf. Pilch 2004:97; Spencer 1999:143). The public sphere, the space which needs to be transgressed for Peter to move from danger to safety, is shared by both episodes.

The discussion above makes it clear that, based on the spatial attributes in the narrative, there is a contrasting structure of two episodes in Acts 12:5-17. This contrasting structure will be taken as organising principle in the rest of this article. ${ }^{7}$

\section{The spheres behind gate and gateway}

One of the obvious spatial contrasts between Acts 12:5-11 and Acts 12:12-17 is the nature of the two spheres behind the gate and the gateway. The prison ${ }^{8}$ could be regarded as a place symbolic of death. ${ }^{9}$ This can be deduced from comparisons with Qumranic material (Garrett 1990:671), the author of Luke-Acts's own parallel use of the terms placed in the mouth of Peter at Luke 22:33 (Wall 1991:636), or the symbolic nature of the darkness (cf. Is 42:7; LXX Ps 107:10) implied when this darkness is driven away by the shining light at the angel's appearance (Ac 12:7) (Parsons 2008:171; Strelan 2004:267). At the very least, the prison is a place of confinement, as is emphasised by the explicit and repeated reference to the guards (Ac 12:4, 6) and Peter's chains (Ac 12:6). Mary's house, on the other hand, is a place of safety and freedom. The locked gateway hints at a sense of confinement here, too, but this security measure should rather be taken as a token of safety (cf. Kistemaker 1990:439). However, the house must be conceived of as relatively large - that is, for a 1st century CE dwelling - as it could hold 'many' (ícavoí - Ac 12:12) people praying (Peterson 2009:365; Witherington 1998:386) and it had a courtyard; moreover, there is free movement inside. These aspects obviate any sense of confinement.

\section{Characters and their locales \\ Peter and the community at Mary's house}

The contrasting nature of prison and house is highlighted by the initial actions of the occupants of each sphere. Whilst Peter sleeps, an action reminiscent of death (Strelan 2004:266), ${ }^{10}$ the church assembled in the house is

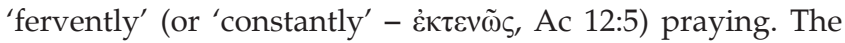

7.The repeated reference to the praying church can serve as an additional argument for dividing Acts 12:5-17 into two episodes. At the start of the argument about structure above, it was pointed out that the construction $\mu \dot{\varepsilon} v \ldots . . \delta \dot{\varepsilon}$ in Acts 12.5 creates a contrast between Peter in prison and the praying church. This praying creates a contrast between Peter in prison and the praying church. This praying church of Acts 12:5 is mentioned again in Acts 12:12. The recurrence of the idea of the praying church is stressed: emphasis is placed on the action of prayer in both

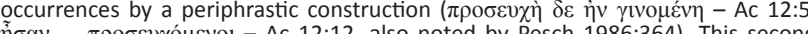

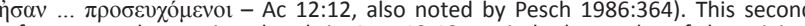
reference to the praying church in Acts 12:12 reminds the reader of the original contrast between Peter and the church in Acts 12:5.

8.The true location of the prison the author of Acts had in mind remains undecided. Two suggestions have been offered: the palace of Herod near the Jaffa gate (e.g. Roloff 1981:189) or the Fortress of Antonia at the opposite end of the city (e.g. Witherington 1998:386).

9.Strelan (2004:269) makes a case for a symbolic interpretation of death through a variant reading in Acts 12:10 pertaining to space in the 'Western' text (in fact,

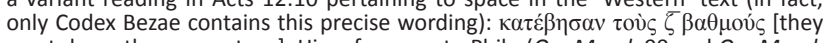
went down the seven steps]. His references to Philo (Op. Mund. 90 and Op. Mund. went down the seven steps]. His references to Philo (Op. Mund. 90 and Op. Mund.
$103-105)$ concerning seven as the perfect number and there being seven stages of $103-105)$ concerning seven as the perfect number and there being seven stages of
life are interesting, but not quite convincing. See Parker (1992:190) for a warning on reading this specific variant reading in a theological or allegorical way.

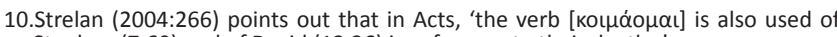
Stephen (7.60) and of David (13.36) in reference to their deaths.' 
active nature of the community's act of prayer is foregrounded by a periphrastic construction, which denotes a continuous

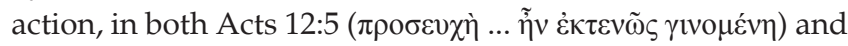

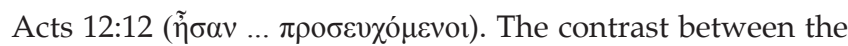
passive Peter (in the dangerous sphere) and active church (praying in the safe sphere) is clear. ${ }^{11}$

Another spatial contrast between Peter and the praying church becomes visible when attention is paid to the experience

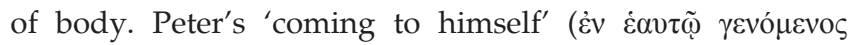
- Ac 12:11) and the church community's 'being beside themselves' ('ं $\xi \dot{\varepsilon} \sigma \tau \eta \sigma \alpha \nu$ - Ac 12:16) both occur after becoming aware of some form of reality (cf. Chambers 2004:96). Some caution is advisable for seeing this as a reference to a true bodily experience in the text. The verb $\dot{\xi} \xi \hat{\sigma} \sigma \tau \eta \mu$ is not uncommon in Luke-Acts, and serves in every other instance to express surprise or wonder. ${ }^{12}$ Certainly the same should be the word's primary meaning here. Peter's 'coming to himself' also finds a parallel in Luke-Acts in Luke 15:17 (cf. Pelikan 2006:147), even though the wording is not entirely the same ( However, the metaphorical language employed still evinces a sense of space. One does not need to postulate outer body experiences (or altered states of consciousness - but cf. Malina \& Pilch 2008:85) to appreciate the contrasting spatial references of the text: the author of Luke-Acts manifestly sets up a play on words through these contrasting metaphorical references to the experience of body.

Two further factors should be considered together with the contrast evoked by the abovementioned references to the experience of body, both concerning the space of reality or illusion - that is, whether that which is experienced in space is real or not. The first of these two factors is Peter's experience of the situation not being real (Ac 12:9), which stands in contrast to the church community's stubborn insistence that their experience is real. In fact, the church community insists on the reality of their experience to the point of accusing Rhoda, the messenger, of madness ( $\mu$ aín - Ac 12:15). That is to say, the church community accuses someone else of having an illusion.

The second factor concerning the space of reality or illusion is Peter's discovery of the reality of the angel (Ac 12:11), ${ }^{13}$

11.A number of other contrasts between Peter, the praying church and other characters are pointed out by Krodel (1986:214), whose list is slightly modified by Parsons (2008:170)

12. Besides Acts $12: 16$, the verb occurs in Luke $2: 47 ; 8: 56 ; 24: 22$; Acts $2: 7,12 ; 8: 9,11$,

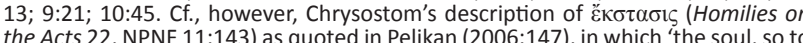
say, was caused to be out of the body.

13.Strelan (2004:266) has suggested that this first angel could refer to Jesus, basing his suggestion on the similar appearance of light $(\varphi \tilde{\omega} c)$ at Jesus's encounter with Paul in Acts 9:3. An identification of the angel with Jesus would support, within the wider debate on Acts 12:5-17, the perceived parallel between Jesus and Peter. There are, however, other occurrences of light coupled with the appearances of angels in Luke-Acts (e.g. Lk 2:9), and the light in Acts 12:7 should rather be taken angels in Luke-Acts (e.g. Lk 2:9), and the light in Acts 12:7 should rather be taken
as a symbol of the otherworldly origin of the angel (Parsons 2008:165; Pervo as a symbol of the otherworldly origin of the angel (Parsons 2008:165; Pervo
2008:304; Weaver 2004:165). Moreover, Kistemaker (1990:436) draws attention to the fact that the angel is identified not as the angel of the Lord, but simply an angel. The present spatial reading stresses the contrast of the real and imagined angels above a possible reading of a parallel between Jesus and Peter here. whereas the church community discovers that their assumption about Peter's angel is wrong (Ac 12:16).${ }^{14}$ These three elements together - experience of body, experience of illusion, and experience of reality - support the contrast between Peter and the church community, adding to the contrasting structure of Acts 12:5-17.

\section{The prison guards and Rhoda}

The two episodes are balanced in yet another way: between cell and gate lie two guard posts to be transgressed (episode 1); between gateway and house a courtyard (episode 2 -

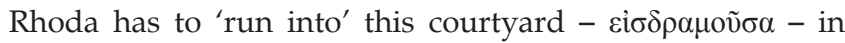
Acts 12:14 (cf. Spencer 1999:143; Van Eck 2003:268). These intermediate planes are the domains of the - for all practical purposes - absent guards (cf. Ac 12:10) and the very lively

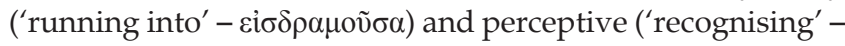
$\dot{\varepsilon} \pi$ iүvoṽ $\alpha$ ) Rhoda (cf. Ac 12:14), the door guard. The absence of the guards is striking, especially when compared to other ancient Rettungswunder-stories. Although the guards are seldom witnesses to the Rettungswunder in these stories (Kratz 1979:467), they are usually explicitly said to be asleep or dead. The absence of such a statement in Acts 12:5-17 has led to many speculations about their implicitly being put to sleep (e.g. Conzelmann 1987:94; Kistemaker 1990:436; Kratz 1979:467; Krodel 1986:222; Peterson 2009:367; Roloff 1981:190). The implication that Peter was chained to two guards (Gallagher 2004:161; Roloff 1981:189; Strelan 2004:266) ${ }^{15}$ heightens the significance of this anomaly. The light at the angel's appearance, after all, could easily have drawn their attention (Pervo 2008:304). The minimal role of the guards is best explained when viewed in comparison with the active Rhoda, who has been convincingly likened to a servus currens [running slave] straight from Roman comedy (Harrill 2000). Furthermore, it is worth noting the gender difference between the guards (who were most certainly men) and Rhoda (a woman). The guards and Rhoda stand in stark contrast to one another.

\section{Peter's movement from danger to safety}

Another overarching spatial concept present in the narrative, Peter's movement from danger to safety, has already been touched upon in passing above. Peter's movement through the three spheres set up by the gate and gateway (prison, street(s) or public space, house) may be seen as ascending steps of safety. The prison is, for obvious reasons, a place of danger. Peter has time to stop and comment on his rescue in Acts 12:11 after the angel has departed, but an escaped convict is not entirely safe in the middle of a public street (cf. Marshall 1980:209). Likewise, Peter is still in a relative

\footnotetext{
14.Weaver (2004:172) sees a parallel - but not a contrast - in the narration of the angel's appearance in prison and Peter's appearance at the door of Mary's house. Scholars most often explain the second angel as the Jewish belief in 'guardian angels' (e.g. Malina \& Pilch 2008:85), although Weaver (2004:175) notes that 'the evidence for this ancient view of angels is scant, at best.' Weaver's counter-

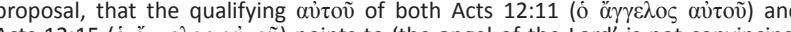

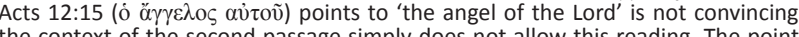
the context of the second passage simply does not allow this reading. The point, in any case, is that the similar wording should draw attention to the comparison of the two angels.

15.Cf. Gallagher (2004:161) and Strelan (2004:266) for references to ancient sources
} where the chaining of prisoners to guards is more explicitly described. 
state of danger when he arrives at Mary's house - were he has to stand outside knocking, 'vulnerable to anyone who might see him' (Parsons 2008:176). In fact, for the plot of the narrative, both Acts 12:11 and Acts 12:12 'produce unbearable suspense' (Pervo 2008:306) because of the almost-but-not-yet state of Peter's safety. ${ }^{16}$ At first glance, then, it is surprising that no mention is made of Peter's entry into the safe space of the house (cf. Chambers 2004:91, 93; Pervo 2008:307; Strelan 2004:270). ${ }^{17}$ The possibility of Peter having entered the house

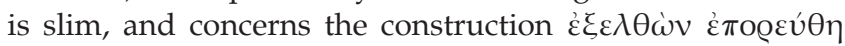
[going (out) he went] in Acts 12:17. Could these two words imply that Peter had first entered a building? Possibly, but the evidence is balanced on a razor's edge: whilst the verb $\dot{\varepsilon} \xi \dot{\varepsilon} \varrho \chi 0 \mu \alpha$ เ could have the sense of 'going out', it could just as easily mean 'depart' (e.g. Ac 11:25). The previous occurrences of $\dot{\xi} \xi \dot{\varepsilon} \mathrm{O} \bigcirc \mu \alpha \mathrm{l}$ in this section of text (Ac 12:9, 10) have the former meaning (i.e. 'depart'), but the use of

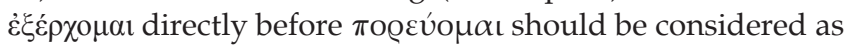
well. The construction of these two words as a participle of

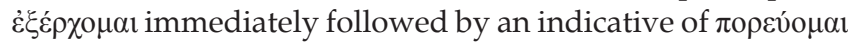
is, except for one instance before the 2nd century $\mathrm{CE},{ }^{18}$ unique to Luke-Acts. The construction occurs in Luke 4:42, 22:39 and Acts 21:5. In the first two of these cases, there has been an explicit foregoing mention of an entry into a building within the relevant narrative section (cf. Lk 4:38; 22:12). In the third, Acts 21:5, previous entry into a building could be implied (cf. Ac 21:4). Hence, the odds are slightly in favour of Acts 12:17's $\grave{\varepsilon} \xi \varepsilon \lambda \theta \omega ́ v$ implying previous movement into an enclosed space, even if this enclosed space is only the courtyard of Mary's house.

Nevertheless, the narrative implies that Peter did not tarry at or in Mary's house. Where Peter went afterwards - and if the author of Luke-Acts did have a specific place in mind

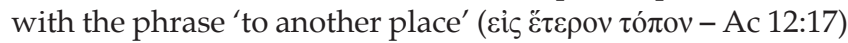
- remains enigmatic (cf. Gaventa 2003:186; Witherington 1998:388), but in view of Peter's initial predicament in Acts 12:5, his movement from danger to safety, and the less than thorough description of his finally entering Mary's house, the present spatial reading supports viewing the reference as a final move towards safety (as proposed by others on different grounds, e.g. Kratz 1979:471; Van Eck 2003:268). ${ }^{19}$

\section{Conclusion}

The present article has argued that spatiality plays an important organising role in the Acts 12:5-17 narrative.

16.Chambers (2004:91) reckons the street before Mary's house to be 'the one place in the pericope which is not "hostile,"' but her depiction of the church community as at best unwelcoming must be somewhat tempered: their unwelcome attitude is not because of their hostility towards Peter, but rather their ignorance of the situation - or their unbelief. The inside of the house that is, the other side of the gateway, should still be considered safer than the street.

17.Both the suggestions proffered by Chambers (2004:91) 'one plausible interpretation of this scene is that it is safer in the street than in a Jerusalem house church run by a woman' and Strelan (2004:270) 'he is no longer part of that community ion [sic] the way that he was previously' seem strained. These details are not explicitly present in the text.

18. Except for Luke-Acts, this construction occurs only in Vitae Aesopi (Vita PI vel Accursiana) 298 line 11 (Eberhard 1872:298); cf. Aesopus Fabulae 22 version 1 line 9 (Hausrath \& Hunger 1970) and Vitae Aesopi (Vita W) section 50a line 1 (Berry 1952), where an adverb is found between participle and indicative.

19.Cf., however, Pervo (2008:308), who notes the similarities between this phrase and

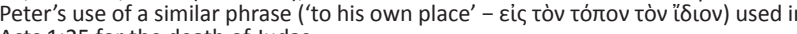
Acts 1:25 for the death of Judas.
TABLE 1: Contrast between stationary and moving actions of Peter in Acts 12:5-17.

\begin{tabular}{ll}
\hline Episode 1 & Episode 2 \\
\hline Stationary action (Peter is chained) & Movement (Peter goes to Mary's house) \\
Movement (Peter exits) & Stationary action (Peter stands) \\
Stationary action (Peter stops) & Movement (Peter goes away) \\
\hline
\end{tabular}

TABLE 2: Contrast between characters in Acts 12:5-17.

\begin{tabular}{ll}
\hline Episode 1 & Episode 2 \\
\hline Peter & Praying community \\
Guards & Rhoda \\
True angel & Falsely supposed angel (Peter) \\
\hline
\end{tabular}

Based on its spatial attributes, the narrative can be divided into two contrasting episodes: Acts 12:5-11 and Acts 12:1217. Although other studies have pointed out some of the 'contrasts which enliven [the author's] account' (Krodel 1986:214), this reading understood the contrasting structure of the section as integral to its composition. The two episodes are framed by stationary and moving actions which are in contrast to the actions within that frame, at least with regard to the main character, Peter. This is graphically represented in Table 1.

Furthermore, keeping in mind the spaces in which characters are located has enabled us to see the comparisons between specific characters in the two episodes. The three character groups of each episode are contrasted in Table 2.

Finally, the notion of movement, so pervasive in this narrative, especially with regard to Peter, suggests that the enigmatic statement about Peter's going 'to another place' is a final move to safety. The contrasting structure initially indicated by Acts 12:5 is counterbalanced in Acts 12:17 by the resolution of the problem set forth in the former verse: Peter has progressed from danger to safety.

\section{Acknowledgements Competing interests}

The author declares that he has no financial or personal relationship(s) which may have inappropriately influenced him in writing this article.

\section{References}

Bar-Efrat, S., 1989, Narrative art in the Bible, Almond Press, Sheffield.

Bauernfeind, O., 1980, Kommentar und Studien zur Apostelgeschichte, Mohr Boulder, Tübingen. (Wissenschaftliche Untersuchungen zum Neuen Testament, 22).

Berry, B.E., 1952, Aesopica 1, University of Illinois Press, Urbana.

Chambers, K., 2004, “Knock, knock - who's there?" Acts 12.6-17 as a comedy of errors', in A-J. Levine \& M. Blickenstaff (eds.), A feminist companion to the Acts of the Apostles, pp. 89-97, T\&T Clark International, London.

Conzelmann, H., 1987, Acts of the Apostles, transl. J. Limburg, A.T. Kraabel \& D.H. Juel, Fortress Press, Philadelphia. (Hermeneia - A Critical and Historical Commentary on the Bible).

Eberhard, A., 1872, Fabulae romanenses Graece conscriptae 1, Teubner, Leipzig.

Gallagher, R.L., 2004, 'Hope in the midst of trial: Acts 12:1-11', in R.L. Gallagher \& P. Hertig (eds.), Mission in Acts: Ancient narratives in contemporary context, pp. 157-166, Orbis Books, Maryknoll. (American Society of Missiology Series).

Garrett, S.R., 1990, 'Exodus from Bondage: Luke 9:31 and Acts 12:1-24', Catholic Biblical Quarterly 52, 656-680.

Gaventa, B.R., 2003, The Acts of the Apostles, Abingdon Press, Nashville. (Abingdon New Testament Commentaries).

Harrill, J.A., 2000, 'The dramatic function of the running slave Rhoda (Acts 12.13-16): A piece of Greco-Roman comedy', New Testament Studies 46(1), 150-157. http:// dx.doi.org/10.1017/\$0028688500000096 
Hausrath, A. \& Hunger, H., 1970, Corpus fabularum Aesopicarum, 2 edn. 1.1, Teubner, Leipzig.

Jervell, J., 1998, Die Apostelgeschichte, Vandenhoeck \& Ruprecht, Göttingen. (Kritischexegetischer Kommentar über das Neue Testament, 3).

Kistemaker, S.J., 1990, Exposition of the Acts of the Apostles, Baker Book House, Grand Rapids. (New Testament Commentary, 5).

Kratz, R., 1979, Rettungswunder: Motiv-, traditions- und formkritische Aufarbeitung einer biblischen Gattung, Peter Lang, Frankfurt am Main. (Europäische Hochschulschriften: Reihe XXIII: Theologie).

Krodel, G.A., 1986, Acts, Augsburg Publishing House, Minneapolis. (Augsburg Commentary on the New Testament).

Macdonald, D.R., 2003, Does the New Testament imitate Homer? Four cases from the Acts of the Apostles, Yale University Press, New Haven.

Malina, B.J. \& Pilch, J.J., 2008, Social-science commentary on the book of Acts, Fortress Press, Minneapolis.

Marshall, I.H., 1980, The Acts of the Apostles: An introduction and commentary, InterVarsity Press, Leicester. (Tyndale New Testament Commentaries).

Marshall, I.H., 1987, 'Apg 12 - ein Schlüssel zum Verständnis der Apostelgeschichte', in C.P. Thiede (ed.), Das Petrusbild in der neueren Forschung, pp. 192-220, R. Brockhaus, Wuppertal.

Parker, D.C., 1992, Codex Bezae: An early Christian manuscript and its text, Cambridge University Press, Cambridge. http://dx.doi.org/10.1017/CBO9780511470479

Parry, D., 1995, 'Release of the captives: Reflections on Acts 12', in C.M. Tuckett (ed.), Luke's literary achievement: Collected essays, pp. 156-164, Sheffield Academic Press, Sheffield. (Journal for the Study of the New Testament Supplement Series, 116).
Parsons, M.C., 2008, Acts, Baker Academic, Grand Rapids. (Paideia). Pelikan, J., 2006, Acts, SCM Press, London. (SCM Theological Commentary on the Bible, 1). Pervo, R.I., 2008, Acts: A commentary, Fortress Press, Minneapolis. (Hermeneia).

Pesch, R., 1986, Die Apostelgeschichte: 1. Teilband: Apg 1-12, Benziger Verlag, Zürich. (Evangelisch-Katholischer Kommentar zum Neuen Testament, 5).

Peterson, D., 2009, The Acts of the Apostles, William B. Eerdmans, Grand Rapids. (The Pillar New Testament Commentary).

Pilch, J.J., 2004, Visions and healings in the Acts of the Apostles: How the early believers experienced God, Liturgical Press, Collegeville.

Roloff, J., 1981, Die Apostelgeschichte, Vandenhoeck \& Ruprecht, Göttingen. (Das Neue Testament Deutsch, 5).

Spencer, F.S., 1999, 'Out of mind, out of voice: Slave-girls and prophetic daughters in Luke-Acts', Biblical Interpretation 7(2), 133-155. http://dx.doi. org/10.1163/156851599X00065

Strelan, R., 2004, Strange Acts: Studies in the cultural world of the Acts of the Apostles, Walter de Gruyter, Berlin. (Beihefte zur Zeitschrift für die neutestamentliche Wissenschaft und die Kunde der älteren Kirche, 126).

Van Eck, J., 2003, Handelingen: De wereld in het geding, Kok, Kampen. (Commentaar op het Nieuwe Testament).

Wall, R.W., 1991, 'Successors to "the Twelve" according to Acts 12:1-17', Catholic Biblical Quarterly 53, 628-643.

Weaver, J.B., 2004, Plots of epiphany: Prison-escape in the Acts of the Apostles, Walter de Gruyter, Berlin. (Beihefte zur Zeitschrift für die neutestamentliche Wissenschaft und die Kunde der älteren Kirche, 131).

Williams, C.S.C., 1964, A commentary on the Acts of the Apostles, Adam \& Charles Black, London.

Witherington, B., 1998, The Acts of the Apostles: A socio-rhetorical commentary, Wm B. Eerdmans, Grand Rapids. 